\title{
Cartilage Oligomeric Matrix Protein
}

National Cancer Institute

\section{Source}

National Cancer Institute. Cartilage Oligomeric Matrix Protein. NCI Thesaurus. Code C131264.

Cartilage oligomeric matrix protein (757 aa, $\sim 83 \mathrm{kDa}$ ) is encoded by the human COMP gene. This protein plays a role in the formation and maintenance of cartilage. 